\title{
Caesar and Road to an Empire: A Hobbesian Reckoning of Rome (60 BC- 44BC)
}

\author{
Abhishek Chakravorty
}

Faculty, Department of English, Midnapore City College, WB, India

Received: 29 Jun 2021; Received in revised form: 19 Jul 2021; Accepted: 28 Jul 2021; Available online: 07 Aug 2021 C2021 The Author(s). Published by Infogain Publication. This is an open access article under the CC BY license (https://creativecommons.org/licenses/by/4.0/).

\begin{abstract}
Julius Caesar was a remarkable man in the history of western civilization. It will not be an exaggeration to say that he is still standing at the center of the history of ancient Rome. His rise to power was during a time when Rome was a Republic being controlled by the wealthy Senate. The rule of the Senate eventually got corrupted by their personal greed. Being a man obsessed with ambition and visions, Caesar saw the error of their ways and he strived for absolute sovereignty by going through a civil war and ending it eventually. In this paper, my aim is to invoke the philosophy of Thomas Hobbes about the 'State of Nature' in the wake of the falling social structure of Rome suffering from the civil war and the corruption of the Senate from 60 BC to 44 BC. I will also analyze Caesar's rise to power and his acceptance by the common populace of Rome by rendering it with the theory of 'Absolutism'. The whole purpose of the paper is to critically pinpoint the major ideological impacts of Hobbes in that period of transition where the Roman republic was becoming the Roman Empire.
\end{abstract}

Keywords-Republic, Empire, History, Transition, Civil war, Absolute sovereignty.

\section{INTRODUCTION}

The transformation of the Roman Empire from its Republican state was a gradual process that came out of the necessity to re-stabilize the already derailed Roman society. During the timeframe of $100 \mathrm{BC}$ to $60 \mathrm{BC}$, the Roman society was fairly corrupted and the members of the Roman Senate were delving themselves in neck-deep lust for political power and money. As a result, the common people of Rome were suffering. Nearly one million inhabitants of the city were continually neglected by their republican leaders. During this time of crisis, one man started to rise to take the whole matter into his own hands to be one of the greatest generals and conquerors of not only Rome but also of the whole world. That man was Julius Caesar. Julius Caesar's rise to power was supported by the common people who wanted him as their leader than the corrupted Roman officials. Caesar's popularity among the citizens of Rome marked the beginning of the change that reshaped the Roman socio-political structure. Rome was ready to bow before a supreme authority- Julius
Caesar. In that context, we can use the philosophy of Thomas Hobbes, who is well known for his political book Leviathan, to understand the reason behind Caesar's popularity and the necessity of the transformation.

\section{HOBBES AND THE STATE OF NATURE}

Thomas Hobbes, the $17^{\text {th }}$-century philosopher, is renowned for his famous but controversial theory of state politicsthe 'social contract theory'. In his philosophy, he has declared that in order for a society to maintain its stability, the people in it must accept the rule of a supreme authority. More clearly, he promoted the monarchical structure of state politics. Hobbes sharpened his ideology during the period of the English civil war and as a result, he understood and equivocated that an absolute government is far better than a civil war (Green, 2). He was against any society and political order that was ready to destroy itself from within. If we try to pinpoint his ideology, we have to say that all but absolute government 
structures are prone to corruption and degeneration. To him, even the most oppressive structures are, "scare sensible, in respect of the miseries, and horrible calamities that accompany a civil war." (Green,3).

Naturally, we tend to think that a state is utopian in nature where the people are themselves judges, juries, and executioners and where individualism is promoted. An individual has all the powers to decide not only his/her fate but also the fates of the others. Hobbes has considered it as a negative attribute that can destabilize society at any moment because the people, as they are individually judgmental, do not follow a base political outline to guide the state harmoniously. No recognized authority is there to enforce any rule or regulation to stop this onslaught of personal judgments. To Hobbes, it is the representation of the 'state of nature'. He famously stated that such a, "dissolute condition of masterlesse men, without subjection to Lawes, and a coercive Power to tye their hands from rapine, and revenge" would destroy the equilibrium growth of any socio-political structure (Collins, 50). There would be, "no place for industry, because the fruit thereof is uncertain; and consequently no culture of the earth; no navigation, nor use of the commodities that may be imported by Sea; no commodious Building; no Instruments of moving and removing such things as require much force; no Knowledge of the face of the Earth; no account of Time; no Arts; no Letters; and which is worst of all, continual feare, and danger of violent death; And the life of man, solitary, poore, nasty, brutish, and short" (Collins, 50). For Hobbes, this chaos is inevitable as long as they are not submitting to the authority of a sovereign power for, "so long a man is in the condition of mere nature, (which is a condition of war,) as private appetite is the measure of good and evil." (Collins, 50)

\section{THE STATE OF NATURE IS THE STATE OF WAR- ROME}

In a state where there is no sovereign ruling power, people try to preserve their own lives by any means necessary. Thus it perpetually puts them in a position where they are constantly trying to survive. People fear that others will take advantage of the situation and secure state resources, lands, grains, spouses, for themselves. It becomes a competitive society where people are trying to use their powers against each other. Hobbes has even stated that some 'vain- glorious' persons try to seize power for themselves to control others. But the whole process creates more problems leading to civil war. In $49 \mathrm{BC}$, Rome faced the same crisis which ultimately led to the destruction of 'Republic' Rome. During the time of Caesar, the Roman Senate became very corrupted. The members valued personal greed above the development of the city of Rome and its inhabitants. We need to understand that during that period the Romans were not merchants or manufacturers. They were not, what we can call, highly productive in nature. The whole Roman Republic depended on the Roman Legions and their generals who invaded other countries and lands and occupied those places. Those lands became parts of the Roman Republic and thus sources of provisions for the Romans. They were important not only provisions but also for slaves. Slavery was rampant and the captured prisoners of wars were used as slaves for various kinds of hard works as well as for gladiatorial games. Basically, it can be said that the Roman Republic followed Agrarianism (Abbot, 19).

In Republican Rome, the Senate was very powerful. They decided the fates of the people of Rome. The members were very competitive in nature and they strived to achieve power for themselves. Before the rise of Julius Caesar, the Senate was torn apart by the conflicts between Crassus and Pompey, two very powerful Roman generals and members of the Senate. Crassus was a wealthy person with multiple sources of economic development, where Pompey was a very successful field general who influenced the Roman people with his splendid victories in the East (Abbot, 25). Their bitterness against each other was not only destroying the stability of the Senate, but also the governing proceedings of the Senate. It was one particular example of what Hobbes has stated, where power has been divided between two groups of people and thus the whole social balance was at risk. Julius Caesar was the only person in Rome, during that time, who saw the error of their ways. Though Caesar had his own political agendas and goals, he tried to create a kind of unity between Crassus and Pompey. Caesar's attempt to unify them is celebrated in Roman history as the $1^{\text {st }}$ Triumvirate. He understood that the legion of three- Crassus's money, Pompey's popularity as a general, and his own political insights- was important to stop the corruption within the Senate and protect Rome from crumbling down. Caesar even gave the hands of his daughter Julia in marriage to Pompey to settle the unity among the trio (Abbot, 45). And in this process, Caesar became the Consul of Rome, the highest position a civilian can get in Roman politics.

But the triumvirate didn't last long because of Caesar's conquest of Gaul between $58 \mathrm{BC}$ and $50 \mathrm{BC}$. Caesar was an ambitious man and a successful general just like Pompey. His thought about his political career was not limited to the consulship. He was aiming for something higher- something that would give him absolute power in the Republic of Rome.Being a master strategist, Caesar understood that to gain that position he needed to capture the hearts of the common people. And the only way to do 
that was through the conquest of a foreign land. His Gallic invasion lasted for eight years and it is still regarded as a crucial period in his political career (Abbot, 28).

Caesar attempted to conquer the Transalpine Gaul, modern-day France. He showed major leadership skills in defeating the Gallic tribes. In those eight years, he conquered nearly 200,000 miles of the foreign land. The conquest of Gaul made Caesar highly popular to the people of Rome and to his own legionnaires (Abbot, 29). According to Hobbes, this was a perfect way of influencing the common populace to accept the rule of someone powerful, a way of popularity that would compel the people to worship a sovereign figure as their monarch. But, for Caesar, it was a challenging job. The other generals and members of the Senate didn't take Caesar's conquest of Gaul from a positive perspective. They felt threatened by his increasing popularity in Rome. Hobbes has discussed that men are shortsighted and cannot look beyond their personal goals. They cannot make a decision that will benefit the larger community. They are caught inside the prisoner's dilemma of game theory.Men tend to become spiteful, envious and jealous when they see an obstacle standing before their drives for desires. Caesar faced the same crisis. Both Crassus and Pompey were threatened with Julius Caesar's achievements. They tried to achieve their own goals through military conquests of their own. Crassus died in his invasion of Parthia. Pompey set his eyes in the unconquered lands of the East. Though Pompey was a great general, his main problem was that he failed to see the cause of Caesar's actions. Pompey sought his glory and power at expense of the Roman citizen, where Caesar's goal was to achieve the power to settle down the anarchy in the Roman society. We will be discussing it later in the paper. This major clash between Caesar and Pompey led to the Roman Civil war in 49 BC.

Caesar's crossing the Rubicon on $10^{\text {th }}$ January, 49 BC officially marked the beginning of the civil war. Rubicon was a small river in the north of Italy flowing into the Adriatic Sea. The river marked the boundary between the northern portions of Italy (hither Gaul) and the southern lands of Italy including the city of Rome. The Roman Senate had strictly stated that no army can cross the river and enter the southern portions; otherwise, it would be considered as an invasion against Rome. The same rule was applicable for any Roman general with Roman legions. In $49 \mathrm{BC}$, the northern portions of Italy came under the control of Caesar because of his Gallic invasion. So, when he crossed the Rubicon, it was a direct challenge to Republic Rome. Crossing the Rubicon has been a famous phrase in the history of the world as it marked the rise of Julius Caesar as the Roman dictator (Abbot, 47).
We have to understand that when Caesar chose to cross the river, he was with his Roman legions. So, it was basically Rome against Rome, thus prompting the civil war. The interesting fact was that none of the legionnaires went against him. Caesar was supported by his comrades and fellow soldiers, though they were going against the Roman constitution. Furthermore, on his way to Rome, Caesar was welcomed by the common people of local Roman towns. Now, according to Hobbesian point of view, people look for stability and peace, and therefore, if they are influenced enough, they will welcome anyone or anything to achieve that state of peace- "peace is good, and therefore also the way or means of peace are good." It is known as 'the laws of nature'. (Green, 27) To Hobbes, people use two strategies to overcome any hardships in their lives- first, Pactum Unionisand second, Pactum Subjectionis(Laskar, 1). The first strategy means that people will create unions to stay together to avoid any trouble and degeneration. The second one implies subjecting themselves under the rule of some sovereign structure or person. In exchange for their subjugation, the sovereign authority will secure and preserve their lands, economic structure, and socio-political harmony. It is the hobbesian 'Social Contract Theory' where the people will voluntarily surrender their freedoms and rights. (Laskar, 2). Caesar's case can be seen from the same point of view where he was welcomed by the people. Such was his popularity. Out of fear of defeat, Pompey and other members of the Senate flew from Rome, leaving the city without any active government and it instantly had a tremendous effect on the people. The city of Rome plunged into chaos. But Caesar ceased his advance towards Rome when he heard the news that Pompey was going to gather armies and allies from Greece. He understood that to bring peace in Rome, Pompey must be defeated for good. On one side Caesar promised the people that who would side with Pompey, they would not be harmed in any way, and on the other side, he himself went to Greece through Brundusium crossing the Adriatic. Again, this generosity of Caesar earned him huge popularity (Abbot, 54). Finally, against all odds, with the help of Mark Antony, Julius Caesar was able to defeat Pompey at Pharsalus in Central Greece on $9^{\text {th }}$ August, 48 BC (Abbot, 62).Pompey escaped to Egypt where he was eventually killed by Ptolemy XIII, ruler of Egypt, thus ending the civil war of Rome.

\section{CAESAR AND ABSOLUTISM}

Hobbes, in his philosophy, has elucidated that with sovereignty absolutism must come. The authority in control must dictate all the spheres of socio-political 
scenario- from powers of legislation to war-making, known asessential rights of sovereignty(Green, 29). From that point of the frame, Hobbes promoted the value of a monarchical power structure in any state.After the end of the civil war, Caesar was forced to stay in Egypt for the Egyptian civil war between Ptolemy XIII and Cleopatra VII. He sent Mark Antony to Rome to deal with the chaos in Rome. Due to Mark Antony's weak management skills, the city of Rome was suffering from riots and starvation. In $45 \mathrm{BC}$, Julius Caesar returned to Rome to take things into his own hands. During this period Caesar had already become the most powerful man in Rome. So, he used his authority to force the Senate to give him the position of Dictator of Romefor ten years.The Roman dictatorship was a long-forgotten official status that was against all the constitutional values of Republican Rome. Caesar knew that Roman politics was broken and the Senate had no potential to restore it. They even lost the support of the people. To avoid any future collapse of the Roman government and return to the state of nature, Caesar chose to have absolute authority above all. He promoted the very concept of 'might is always right.' (Laskar, 2)

During his time of being the dictator of Rome, Caesar introduced various policies to restore the vitality of the Roman society. He issued new grain laws, constructed new buildings to give the people jobs to earn their livings; he created a strong business relationship with Egypt because of his affair with Queen Cleopatra. Even he started a new calendar system that is still being used today. Under his dictatorship, the Roman people found stability and preservation.

\section{CONCLUSION}

Caesar understood that Rome had a future with him and his absolute monarchy. He was in favor of a dynasty.He himself started to wear purple robe which was a symbol of the ancient Roman monarchy. To the Roman Senate, it was an act against their republican values, against the very identity of Rome. One of the members of the Senate was Brutus, son of Caesar's mistress Servilia. Brutus considered Caesar a magnificent figure, capable of everything. Caesar was a father figure to him and Brutus got many favors from Caesar as he considered Brutus like a son. But, it was Brutus who betrayed him at last in a conspiracy of the Senate against Julius Caesar. Brutus was not someone who was using Caesar to gain political power and his betrayal was not political or personal. To Brutus, Caesar's act as an absolute authority was a slap against everything he held dear in Rome, even against his identity as a Roman citizen. Finally, Julius Caesar was assassinated on $15^{\text {th }}$ March, 44 BC by Brutus and other members of the
Senate. In Shakespeare's Julius Caesar, Brutus rhetorically defended his act,

"Had you rather Caesar were living, and die all slaves, than that Caesar were dead, to live all free men?" (III.ii.2325)

To Brutus, Caesar was associated with slavery and the loss of freedom. But in reality, after the assassination, "the republic, however, scarcely outlives Caesar." (Blits, 41) Again to quote from Shakespeare's Julius Caesar, "Brutus and Cassius/ Are rid like madmen through the gates of Rome."(III.ii.270-271). We have to understand the massive influence Caesar had on the people of Rome. Though he became a dictator, that dictatorship was for the benefit of the common people. People of Rome saw that. Thus, he became a legend among them. The assassination never strengthened the Republic; it only paved the way to the rise of Octavius Caesar, nephew of Julius Caesar, the first Roman Emperor. Julius Caesar was a giant of a man who was standing at a period of transition. He was not only standing but also he was at the center of it. In 42 BC, the Roman Senate declared Caesar as one of the gods. The month of July has been named to honor him. Julius Caesar not only influenced the history of Rome, but also the history of the whole world.

\section{REFERENCES}

[1] Abbot, J. History of Julius Caesar. SMK Books. 2018.

[2] Bilts, Jan H. Caesarism and the End of Republican Rome: Julius Caesar, Act I, scene i, The Journal of Politics, Feb., 1981, Vol. 43, No. 1, pp. 40-55.

[3] Collins, J. The Allegiance of Thomas Hobbes. Oxford: Oxford University Press. 2005.

[4] Finn, S. Thomas Hobbes and the Politics of Natural Philosophy. London: Continuum Press. 2006.

[5] Green, M. Authorization and Political Authority in Hobbes. Journal of History of Philosophy, 62 (3): 25-47.

[6] Hobbes, T. Leviathan. London: Wordsworth Classics of World Literature. 2014.

[7] Laskar, M. E. Summary of Social Contract Theory by Hobbes, Locke and Rousseau. SSRN Electronic Journal. April, 2013.

[8] Shakespeare, W. Julius Caeser. UK: Penguin Classics. 2015.

[9] Taylor, L. R. The Rise of Julius Caesar. Greece \& Rome. Mar., 1957, Vol. 4, No. 1, pp. 10-18. 